\title{
AZ ALUHAB® ULTRAHANGOS FORGÁCSOLÁSI LEHETŐSÉGEI MARÁSNÁL
}

\section{POSSIBILITIES OF ULTRASONIC MACHINING AT ALUHAB® MILLING}

\author{
Kun Krisztián ${ }^{1}$, Líska János ${ }^{2}$ \\ Kecskeméti Föiskola, Gépipari és Automatizálási Müszaki Föiskolai kar, Jármü- \\ technológia Tanszék, Magyarország, Kecskemét, Izsáki út 10. \\ ${ }^{1}$ Telefon:+3676516387, kun.krisztian@gamf.kefo.hu \\ ${ }^{2}$ Telefon:+3676516380, liska.janos@gamf.kefo.hu
}

\begin{abstract}
Today, special materials are used at more and more places. These materials generally are characterized by excellent mechanical properties. The aluminium foam is one type of special material. This material can be characterized by ultra-light weight and very high strength. Moreover, this material has very good vibration absorbing capability due to the cellular structure. The aim of our research is to investigate the possibilities of machinability of aluminum foam with help of ultrasonic technology

Keywords: aluminium foam, composite, ultrasonic milling

\section{Összefoglalás}

Napjainkban az ipar egyre több területén használnak különleges anyagokat. Ezek az anyagok általában kiváló mechanikai tulajdonságaikkal rendelkeznek. Az alumíniumhab is ezek közé az anyagok közé tartozik. Ez az anyag rendkívül könnyü és emellett nagy teherbírással rendelkezik. Az anyag rezgéselnyelő képessége, a cellás szerkezetének köszönhetően meglehetősen jó. Kutatásunk célja feltárni az alumíniumhab forgácsolásának lehetőségeit az ultrahangos technológiával.
\end{abstract}

Kulcsszavak: alumíniumhab, kompozit, ultrahangos marás

\section{Bevezetés [2] [3] [4]}

A fémhabokhoz hasonló sejtes szerkezetü anyagok egyre népszerübbek a könnyü szerkezetek tervezése során. Az 1948-as kezdeti kutatások óta sokféle fémhabot alkottak. Számos fém és ötvözet habosítható, de az alumíniumhabra jelent meg a legnagyobb piaci igény.

$\mathrm{Az}$ Aluinvent Zrt. technológiájával meghatározott cellaméretü és mechanikai tulajdonságokkal rendelkező alumíniumhab gyártható (1. ábra).
A cellaméret változtatásával rengeteg különböző sürüségü és mechanikai tulajdonságú hab hozható létre.

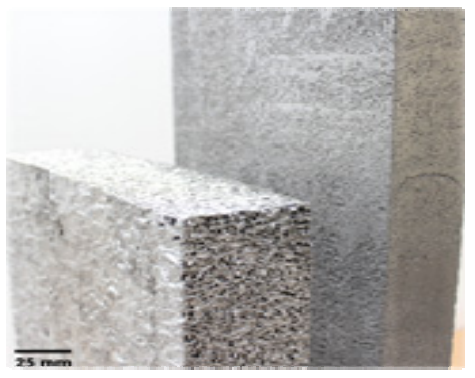

1. ábra. $A L U H A B{ }^{\circledR}$ tömbök 


\section{Megmunkálási lehetőségek ku- tatása [1]}

Az ALUHAB ${ }^{\circledR}$ laminálható, ezért felhasználható akár szendvics szerkezetü kompozitok alapanyagaként. Az első, anyaghoz kapcsolódó forgácsolási vizsgálatokat szendvics szerkezetü kompoziton végeztük. (2. ábra)

\subsection{A kutatást megelőző kísérletek}

Két különböző ALUHABß-ot szénszál erősítésű kompozittal (CFRP) lamináltunk (2. ábra). A vizsgált alumíniumhabok tulajdonságait az 1. táblázat mutatja.

1. táblázat. Megelözö kísérletek alapanyagai

\begin{tabular}{|c|c|c|}
\hline & Anyag jelölése & \multicolumn{2}{|c|}{$\begin{array}{c}\text { Sürüség } \\
{\left[\mathbf{g} / \mathbf{c m}^{\mathbf{3}}\right]}\end{array}$} \\
\hline 1. & AlSi10_6AlO6 & 0,4 \\
\hline 2. & $6061 \_8 \mathrm{AlO} 6 \mathrm{Mg}$ & 0,9 \\
\hline
\end{tabular}

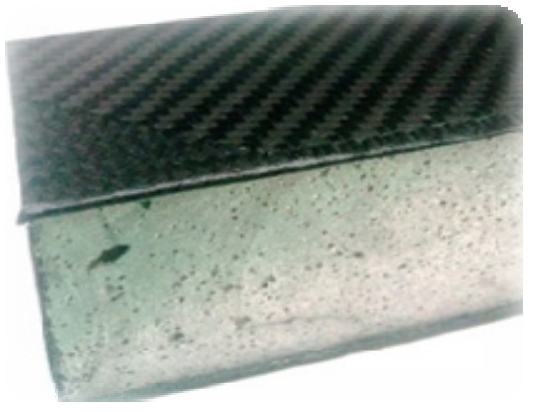

2. ábra. Megelözö kisérletekhez használt, $0,9 \mathrm{~g} / \mathrm{cm}^{3}$ sürüségü, laminált próbatest

A CFRP rétegek elkészítéséhez előre impregnált kompozit lemezt használtunk. A kísérletek során 3 különböző fúróciklus összehasonlítását végeztük, ehhez rezgésdiagnosztikát és forgácsolási erőket mértünk. Alapvetően ezen anyag forgácsolása nem bonyolult, de számos további tényező teszi mégis nehézkessé:

- Szálasodás a CFRP rétegen
- Intenzív szerszámkopás az ALUHAB ötvözői miatt

- Az ALUHAB celláinak elkenődése, negatív sorja (!)

Az alumíniumhab forgácsának eltávolítása a lineáris vezetékekről kiemelten fontos jelentős abrazív hatása miatt. A szerszámgépek védelme tehát szükségszerü. A kísérlet során tapasztalt forgácsalakok láthatók a 3. ábrán.

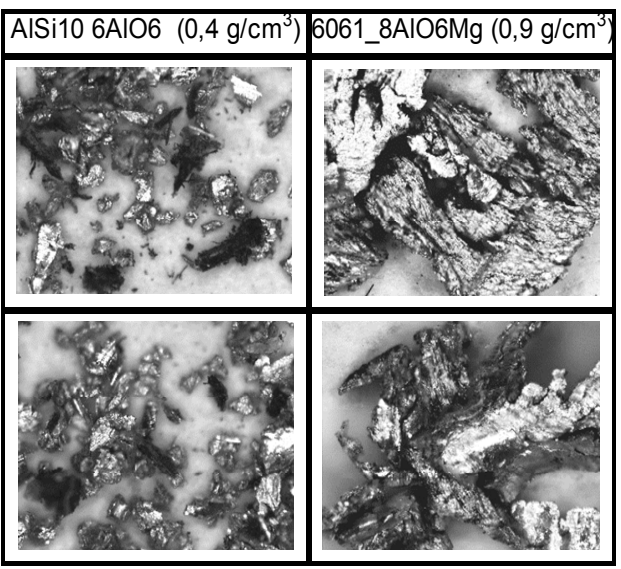

3. ábra. Megelözö kísérleteknél jelentkezö forgácsalakok 80x nagyitásban

\subsection{Az ALUHABß forgácsolása ultra- hangos megmunkáló gépen}

A kísérleti eredményekből arra következtettetünk, hogy pontos technológiai ajánlásokhoz további vizsgálatokra van szükség.

Lehetőségünk nyílt németországi partnerünknél, a DMG Mori Stipshauseni gyárában ultrahangos megmunkáló gépen kísérletet végeznünk. Korábbiaktól eltérően már nem fúrás, hanem marás müveleteket végeztünk.

\subsubsection{A DMG ultrahangos eljárása [5]}

Az ultrahangos, Ultrasonic technológián alapuló megmunkáló gép központi eleme a speciálisan erre a célra kifejlesztett orsó az úgynevezett HSK szabványnak megfelelö szerszámrendszerrel. Az ultrahangos tech- 
nológia nagyfrekvenciáját induktív úton viszik át az orsóról az Ultrasonic HSK befogójára, amely (egy piezo kristályon keresztül) rezgési állapotba hozza a forgácsoló szerszámot. Az oszcillációval akár másodpercenként ötvenezerszer létrejön és megszakad a kontaktus a szerszám és a munkadarab között. A technológiát alkalmazva a forgácsok csak kis darabokban válnak le a munkadarab felületéröl. A technológia elvi vázlatát mutatja a 4. ábra.

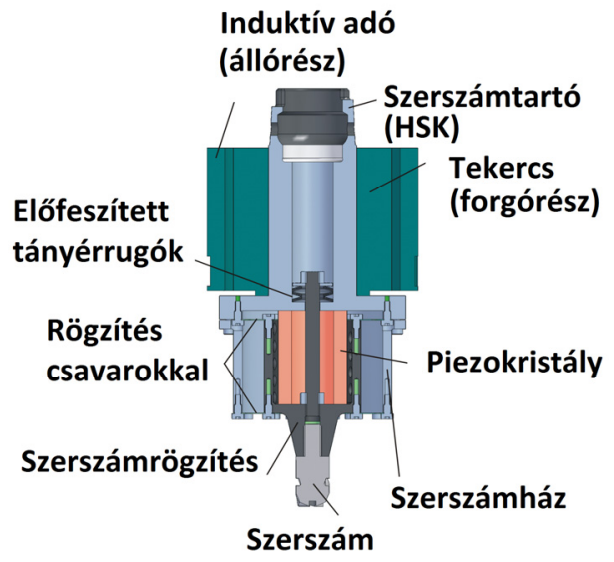

4. ábra. DMG - Sauer Ultrasonic technológia [6]

2.2.2 ALUHAB® horonymarása DMG Ultrasonic megmunkálóközponton

A kísérlet helye:

- Németország, Stipshausen

DMG Mori - Sauer kutatóüzem.

A felhasznált ALUHAB ${ }^{\circledR}-$ ok tulajdonságai:

2. táblázat. Az elögyártmányok típusai

\begin{tabular}{|c|c|c|}
\hline & Anyag jelölése & $\begin{array}{c}\text { Sürüség } \\
\text { g/cm3] }\end{array}$ \\
\hline 1. & AlSi10 6AlO6 & 0,4 \\
\hline 2. & $60618 \mathrm{AlO} 6 \mathrm{Mg}$ & 0,9 \\
\hline
\end{tabular}

Felhasznált mérőeszközök:

- Digitális mikroszkóp,

- Hőkamera: Flir T360.
Szerszámgép típusa:

DMG Mori Ultrasonic 85 monoBlock ${ }^{\circledR}$.

Felhasznált szerszámok:

1. bevonatos keményfém ( $3 \mathrm{db}$.),

2. polírozott felületü, keményfém ( $3 \mathrm{db}$.).

$\mathrm{Az}$ alumíniumhab tulajdonságai inhomogén, cellás szerkezete miatt nagymértékben megváltoznak hütő-kenő folyadék használata esetén, ezért kizárólag sürített levegővel hütöttük a szerszámot.

A kísérlet során mindkét anyagon, kéttípusú szerszámmal, 3-3 forgácsolósebesség értékkel, $50 \mathrm{~mm}$ hosszúságú hornyokat készítettünk állandó fogásmélységgel $\left(\mathrm{a}_{\mathrm{p}}\right)$ és fogankénti elötolással $\left(\mathrm{f}_{\mathrm{z}}\right)$. Minden hornyot külön-külön szerszámmal forgácsoltunk.

Alkalmazott forgácsolósebesség értékek: $\mathrm{v}_{\mathrm{c}}=200 ; 300 ; 500 \mathrm{~m} / \mathrm{min}$.

$\mathrm{Az}$ 1. típusú, három élü szerszámmal mindössze két horony marása után látható volt a feladatra való alkalmatlansága. A szerszám felületéhez adhéziós kötéssel tapadt a leváló forgács. A nagyobb sürüségü alumíniumhabnál, a fogásmélység növekedésével a szerszámon képződő élrátét már akkorának bizonyult, hogy az megakadályozta a forgácseltávolítást, elzárta a maró hornyait (5. ábra). Ez a szerszám töréséhez vezetett.

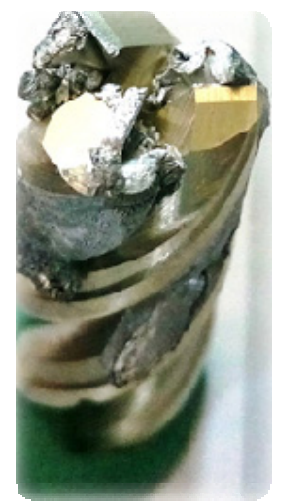

5. ábra. Adhéziós kötés a szerszám és a munkadarab között 
A második szerszámtípus már polírozott felületü volt, valamint csak két éllel rendelkezett. Ez előnyösebbnek bizonyult, a forgács akadálymentesen tudott távozni a forgácsolási zónából.

A szerszámot a horonyból való kilépéskor hőkamerával fotóztuk (6. ábra), figyelve a maximális hőmérsékletet.

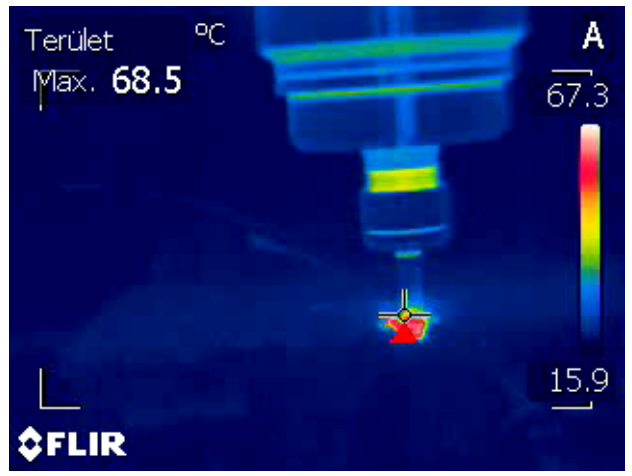

6. ábra. Az ultrahangos forgácsolásnál a horony kilépésénél nem tapasztalható kimagasló hömérsékleti érték

A szerszámokat ezt követően mikroszkóppal vizsgáltuk. A mikroszkópi képek alapján megállapítható, hogy élrátét továbbra is keletkezett. (7.ábra) $\mathrm{Az}$ egyes forgácsolósebesség értékeknél számottevő különbség nem jelentkezett.

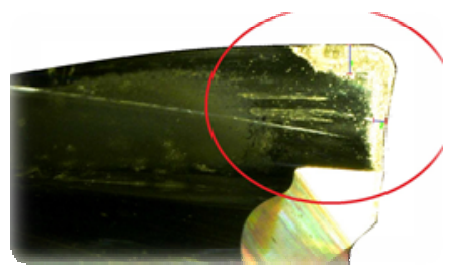

7. ábra. Élrátét a 2. típusú szerszámon

\section{Következtetések}

Az ultrahangos megmunkálás előnye leginkább a darabon mutatkozott:

Míg a konvencionális gépeken az anyag kenődött (negatív sorjaképződés), a felület elveszítette cellás szerkezetét, addig az ult- rahangos megmunkálásnál a felület megőrizte az eredeti küllemét.

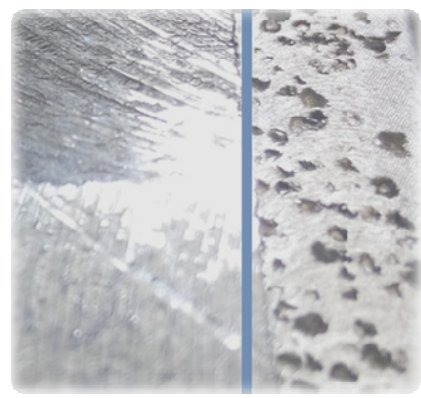

7. ábra. A 6061 (8AlO6Mg), 0,9 g/cm3 sürüségü ALUHAB ${ }^{\circledR}$ felülete konvencionális (balra) és ultrahangos (jobbra) marás után

Az ultrahangos technológia használata mindenképpen elönyös, amennyiben a forgácsolt darab végfelhasználásánál a struktúra megőrzése lényeges. Az élrátét képződésének minimalizálásához további kutatások szükségesek az ultrahangos technológiával.

Jelen kutatás jó kiindulási alapja a későbbi $\mathrm{K}+\mathrm{F}$ pályázatoknak.

\section{Szakirodalmi hivatkozások}

[1] Líska János, Krisztián Kun, Roland Sándor, Norbert Babcsán: Drilling of CFRPAluhab ${ }^{\circledR}-C F R P$ sandwich structure TEAM 2015, 7th International Scientific and Expert Conference of the International TEAM Society, ISSN 978-86-7083-876-5, Belgrade 2015.

[2] Banhart, J., D. Weaire: On the Road Again: Metal Foams Find Favor, Physics Today, Jul 2002, pp.37-42.

[3] N. Babcsan, S. Beke, P. Makk: Method for producing a metal foam by oscillations and thus obtained metal foam product, Patent WO2010_064059 A2.

[4] Leitlmeier, D., H.P. Degischer, H.J. Flankl. 2002. Development of a foaming process for particulate reinforced aluminum melts, Advanced Engineering Materials, 10.

[5] GyártásTrend http://www.gyartastrend.hu/gepgyartas/cikk/f ogpotlasok_automatikusan (2016.02.26.)

[6] Uni-Hannover Teil projekt (figure) http://www.sfb653.uni-hannover.de/enus/Pages/Teilprojekt-T4.aspx (2016.02.26) 